\title{
IRON UPTAKE AND INCREASED INTRACELLULAR ENZYME ACTIVITY FOLLOW HOST LACTOFERRIN BINDING BY TRICHOMONAS VAGINALIS RECEPTORS
}

\author{
BY KENNETH M. PETERSON AND JOHN F. ALDERETE
}

From the Department of Microbiology, The University of Texas Health Science Center at San Antonio, San Antonio, Texas 78284

Trichomonal vaginitis caused by Trichomonas vaginalis represents the most frequently acquired protozoan infestation (1-4). Despite the emergence of trichomoniasis as a major sexually transmitted disease, only limited information is available concerning $T$. vaginalis mechanisms of disease pathogenesis. Determinants of pathogenicity have not been identified, although contact-dependent cytolytic events mediating destruction of host cells and trichomonal hemolytic activity have been reported $(2,5,6)$. The parasite molecules responsible for these observations, however, are still unknown.

Because acquisition of host substances is important to the pathogenic mechanisms of microorganisms (7-14), we have attempted to define the molecular interactions of host macromolecules with $T$. vaginalis $(15-17)$. Our approach has involved a step-wise examination of plasma protein acquisition, identification of host proteins enriched onto trichomonad surfaces, and elucidation of biological properties conferred upon $T$. vaginalis through binding and uptake of certain host molecules $(16,17)$.

In a recent study (17) we reported the avid association of several host plasma proteins, including an iron-binding protein, with the surface of $T$. vaginalis. Transferrin and lactoferrin are two proteins, with high binding affinities for ferric ions $(18,19)$, which are involved in iron sequestration within host tissues. Transferrin is found predominantly in plasma, while lactoferrin is produced by acinar cells of mucosal surfaces and is found in milk, semen, tears, cervical secretions, polymorphonuclear leukocytic granules, and pus (20-22). Because acquisition of host iron through specific mechanisms may be important to $T$. vaginalis (23-25), we decided to characterize further the interaction of these two iron-binding proteins with $T$. vaginalis. These data show that iron accumulation and increased intracellular enzyme activity are associated with the binding of human lactoferrin by specific receptors on $T$. vaginalis.

Materials and Methods

Growth of Organisms. T. vaginalis strains NYH 286, 272, ATCC 30001, 30236, RU 375 , and IR 78 were kindly provided by Miklós Müller, The Rockefeller University, New

J. F. A. was supported by Public Health Service grants AI-18768 and AI-19I 42 from the National Institutes of Allergy and Infectious Diseases of The National Institutes of Health, and was the recipient of Research Career Development Award K04 AI00584 from the National Institutes of Health. Correspondence should be addressed to Dr. John F. Alderete.

398 J. ExP. MED. (C) The Rockefeller University Press · 0022-1007/84/08/0398/13\$1.00

Volume 160 August $1984 \quad 398-410$ 
York. Strains JHHR and JHHW were provided by Michael Spence, Johns Hopkins. These strains were passaged daily in Diamond's trypticase-yeast extract-maltose (TYM) ${ }^{1}$ medium (26) supplemented with $10 \%$ normal human plasma. Only late log stage parasites were used in these studies (15). Where indicated, low density lipoproteins at levels equivalent to those found in plasma were added to the medium. The growth properties of $T$. vaginalis in low density lipoprotein-supplemented medium have been recently described (17).

Lactoferrin and Transferrin Preparation. Human milk lactoferrin was purified by heparin-agarose chromatography (27). Briefly, $300 \mathrm{ml}$ of pooled human milk donated by La Leche League (San Antonio, TX) was thawed and the cream removed by centrifugation at $10,000 \mathrm{~g}$ for $20 \mathrm{~min}$. The skim milk was adjusted to $\mathrm{pH} 4.7$ with $1 \mathrm{~N} \mathrm{HCl}$ and incubated at $40^{\circ} \mathrm{C}$ for $30 \mathrm{~min}$ followed by centrifugation at $10,000 \mathrm{~g}$ for $30 \mathrm{~min}$. The whey was removed and dialyzed against 2 changes of $0.05 \mathrm{M} \mathrm{NaCl}$ in $0.005 \mathrm{M}$ barbituric acid (Sigma Chemical Co., St. Louis, MO), pH 7.4. This material was then loaded onto a $1 \times$ $45 \mathrm{~cm}$ heparin-agarose column equilibrated with the barbital buffer described above. After washing the column with starting buffer, a $500-\mathrm{ml}$ linear gradient from $0.05 \mathrm{M}$ to $1.0 \mathrm{M} \mathrm{NaCl}$ in starting buffer was applied at $15 \mathrm{ml} / \mathrm{h}$. The peak corresponding to lactoferrin was pooled and dialyzed against PBS. Lactoferrin was $>99 \%$ pure as determined by $\mathbf{7 . 5 \%}$ polyacrylamide gel electrophoresis and staining. Serum transferrin (Sigma) was also evaluated for purity. Protein solutions of lactoferrin and transferrin were prepared in phosphate-buffered saline (PBS; $137 \mathrm{mM} \mathrm{NaCl}, 2.7 \mathrm{mM} \mathrm{KCl}, 4.6 \mathrm{mM}$

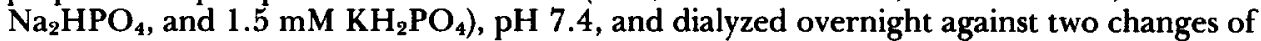
$0.1 \mathrm{M}$ citrate acetate buffer ( $\mathrm{pH} 4.0$ ) followed by one change of distilled water and two changes of a $40 \mathrm{mM}$ Trizma base (Sigma)-20 mM sodium bicarbonate buffer ( $\mathrm{pH} 7.4$ ) (28). Saturation of transferrin and lactoferrin with iron was achieved by addition of 30 $\mu \mathrm{g}$ of $\mathrm{FeCl}_{3}$ to $5 \mathrm{mg}$ of protein in the Tris-bicarbonate buffer. Unbound iron was removed by dialysis against PBS.

Transferrin and lactoferrin were radioiodinated by lactoperoxidase as described previously $(16,17,29)$ using $1.0 \mathrm{mCi}$ of $\mathrm{Na}^{125} \mathrm{I}$ (Amersham Corp., Arlington Heights, IL). Unbound radioactivity was removed using a $1 \times 15 \mathrm{~cm}$ Sephadex G25 (Pharmacia, Piscataway, NJ) column. Efficiency of labeling was determined by trichloroacetic acid precipitation (29).

For studies examining the uptake of ferric iron, ${ }^{59} \mathrm{FeCl}_{3}$ (Amersham) was added to transferrin and lactoferrin as above in the Tris-bicarbonate buffer for $30 \mathrm{~min}$ at $22^{\circ} \mathrm{C}$. Unincorporated iron was removed by chromatography in a $1 \times 10 \mathrm{~cm}$ Sephadex G25 column followed by overnight dialysis against two changes of PBS. These radiolabeled preparations were $\sim 50 \%$ saturated with ${ }^{59} \mathrm{Fe}^{3+}$ as determined by incorporated radioactivity.

Cell Binding Assays. Live, motile parasites were washed twice in PBS to remove loosely bound medium components (17) and resuspended in PBS to a density of $1 \times 10^{8}$ cells/ $\mathrm{ml} .100-\mu \mathrm{l}$ aliquots of this parasite suspension were then added to $1.5 \mathrm{ml}$ siliconized conical polypropylene microfuge tubes pretreated with $1 \%$ horse serum (12). Different amounts of protein preparations were added to the parasites with a final volume of $500 \mu \mathrm{l}$. Incubation was at both $4^{\circ} \mathrm{C}$ and $37^{\circ} \mathrm{C}$ for various times with occasional gentle shaking. Trichomonads were separated from unbound material by gentle centrifugation (17), followed by two washings in ice cold PBS. Finally, pelleted organisms were resuspended and transferred to another tube before determination of avidly bound cpm. Competition experiments were performed similarly with increasing amounts of unlabeled proteins mixed with radiolabeled proteins before addition. Ratios of unlabeled to iodinated proteins are indicated in the legend of Fig. 4, illustrating the competition experiment.

Pyruvate/Ferredoxin Oxidoreductase Activity. T. vaginalis enzyme activity was monitored spectrophotometrically at $30^{\circ} \mathrm{C}$, utilizing methylviologen as an artificial electron acceptor $(23,24)$. Briefly, an assay mixture containing $180 \mathrm{mM} \mathrm{Na}_{2} \mathrm{PO}_{4}$ and $120 \mathrm{mM} \mathrm{NaHPO}_{4}$,

\footnotetext{
${ }^{1}$ Abbreviations used in this paper: Kd, kilodalton; PAGE, polyacrylamide gel electrophoresis; PBS, phosphate-buffered saline; PMSF, phenylmethylsulfonylfluoride; RIP, radioimmunoprecipitation; SDS, sodium dodecyl sulfate; Staph A, protein A-bearing Staphylococcus aureus; TYM, trypticaseyeast extract-maltose; $Z(3-12)$, Zwittergent 312 .
} 
pH 7.0, $16 \mathrm{mM}$ methylviologen, $0.04 \mathrm{mM}$ coenzyme A, $570 \mathrm{mM}$ 2-mercaptoethanol, and $0.1 \%$ Triton X-100 was prepared. The solution was placed in a rubber-stoppered quartz glass cuvette and flushed with deoxygenated $\mathrm{N}_{2}$. Parasites grown under different conditions were washed twice with anaerobic phosphate buffer $\left(180 \mathrm{mM} \mathrm{Na} 2 \mathrm{HPO}_{4}\right.$ and 120 $\mathrm{mM} \mathrm{NaHPO}, \mathrm{pH} 7.0$ ) and introduced into the assay mixture. After additional $\mathrm{N}_{2}$ flushing, $4 \mathrm{mM}$ (final concentration) pyruvate was added. The absorbance at $600 \mathrm{mM}$ was monitored using a Beckman model 25 spectrophotometer. Results are expressed as nanomoles of reduced methylviologen formed per minute per $10^{7}$ cells (24).

SDS-PAGE and Fluorography. One-dimensional SDS-PAGE was performed according to Laemmli (30), using $1.5-\mathrm{mm}$ slab gels consisting of a $3 \%$ stacking and $7.5 \%$ separating gel (15). After electrophoresis, gels were fixed and dried for exposure to x-ray film (17) or processed for fluorography (15). Molecular weight standards were purchased from BioRad Labs (Richmond, CA).

Affinity Purification of Trichomonad Lactoferrin-binding Proteins. A total of $5 \times 10^{9}{ }^{95} \mathrm{~S}$ labeled (15) or surface radioiodinated trichomonads (31) were resuspended in $10 \mathrm{ml}$ PBS containing $1 \%$ (wt/vol) Zwittergent 3-12 [Z(3-12)] (Calbiochem-Behring Corp., La Jolla, $\mathrm{CA}$ ) detergent with $0.01 \%$ (wt/vol) phenylmethylsulfonylfluoride (PMSF). Trichomonads were solubilized by gentle homogenization and insoluble material removed by centrifugation at $40,000 \mathrm{~g}$ in a Sorvall RC-5B refrigerated superspeed centrifuge for $60 \mathrm{~min}$. The soluble trichomonal extract was then further diluted in PBS-0.01\% PMSF to give a final $\mathrm{Z}(3-12)$ concentration of $0.1 \%$. Chromatography was performed on a $1 \times 5 \mathrm{~cm}$ lactoferrinSepharose (32) affinity column followed by washing with PBS-0.01\% PMSF. The adherent material was eluted with $3 \mathrm{M}$ potassium thiocyanate, $\mathrm{pH} 7.2$, and dialyzed against PBSPMSF before SDS-PAGE-autoradiography.

Immunoprecipitation of Lactoferrin-trichomonad Receptor Complexes. A volume of $5 \times$ $10^{7}$ solubilized, ${ }^{35} \mathrm{~S}$-labeled parasites prepared as described above was aliquoted into individual microfuge tubes. $30 \mu \mathrm{g}$ of human lactoferrin or serum transferrin was then added to the samples. and incubated overnight at $4^{\circ} \mathrm{C}$ with constant gentle rocking. 20 $\mu \mathrm{l}$ of specific antiserum to lactoferrin or transferrin was then added for an additional $6 \mathrm{~h}$ followed by a 2-h incubation with washed formalin-fixed protein A-bearing Staphylococcus aureus (Staph A) (31). Receptor-ligand-antibody complexes were then selectively removed by pelleting the Staph A. The Staph A were then washed twice with PBS-0.01\% Z(3-12) before solubilization of receptor-ligand complexes (31) for SDS-PAGE-fluorography. High-titered monospecific antiserum against lactoferrin and transferrin were generated in New Zealand White rabbits using standard immunizing regimens (15). Prebleed serum served as a control for these assays.

\section{Results}

Time Course and Temperature-dependent Lactoferrin Binding. The time course binding of ${ }^{125} \mathrm{I}$-labeled human lactoferrin to $T$. vaginalis at both $4^{\circ} \mathrm{C}$ and $37^{\circ} \mathrm{C}$ is shown in Fig. 1. The rates of acquisition and the amount of lactoferrin bound were similar at both temperatures, although $\sim 20 \%$ more radioactivity was associated with trichomonads at the elevated temperature. Steady state binding was demonstrated at $37^{\circ} \mathrm{C}$ for up to $120 \mathrm{~min}$. These kinetic studies implicate the presence of specific membrane sites for trichomonal acquisition of this host substance. The increased binding observed at $37^{\circ} \mathrm{C}$ may be due to nonspecific interactions or may reflect the increased fluidity of the parasite membrane at $37^{\circ} \mathrm{C}$. Alternatively, additional synthesis or expression of membrane receptors at this temperature may result in enhanced specific acquisition.

Placement of organisms in PBS at $4^{\circ} \mathrm{C}$ or $37^{\circ} \mathrm{C}$ after maximal binding of iodinated lactoferrin $(40 \mathrm{~min})$ resulted in release of lactoferrin into the supernatant (Table I). $\sim 75 \%$ of bound material dissociated from intact organisms after an additional 30-min incubation and was recovered in supernatant. No alteration 


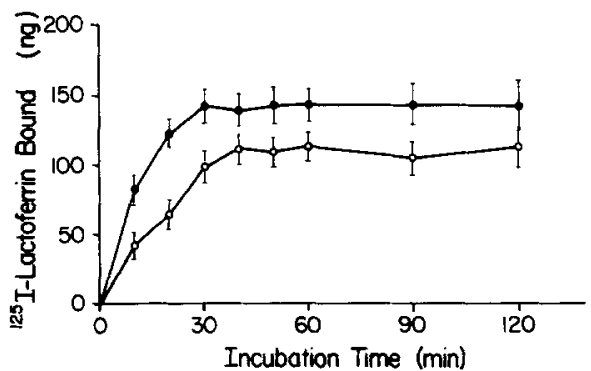

FIGURE 1. Representative time course binding of ${ }^{125}$ I-labeled human lactoferrin to $T$. vaginaiis. Organisms were suspended at a density of $1 \times 10^{7}$ parasites in a $0.5 \mathrm{ml}$ final volume and incubated with $200 \mu \mathrm{g}$ of ${ }^{125} \mathrm{I}$-labeled-lactoferrin at $4^{\circ} \mathrm{C}(0)$ or $37^{\circ} \mathrm{C}(0)$. The amount of cell associated radioactivity was determined as described in Materials and Methods. Results of duplicate determinations of a single experiment are shown.

TABLE I

Release of ${ }^{125} I$-Lactoferrin from $T$. vaginalis Surfaces

\begin{tabular}{ccc}
\hline Time of incubation & $\begin{array}{c}\text { Incubation } \\
\text { temperature }\end{array}$ & $\begin{array}{c}\text { cpm associated with* } T . \\
\text { vaginalis }(\% \text { remaining) }\end{array}$ \\
\hline 0 & $4^{\circ} \mathrm{C}$ & $36,000(100)$ \\
5 & & $31,000(86)$ \\
15 & & $18,000(51)$ \\
30 & & $9,000(25)$ \\
45 & & $8,000(23)$ \\
& $37^{\circ} \mathrm{C}$ & \\
5 & & $46,000(100)$ \\
15 & & $38,000(83)$ \\
30 & & $16,000(45)$ \\
45 & & $10,000(30)$ \\
\hline
\end{tabular}

* $1 \times 10^{7}$ organisms in $0.5 \mathrm{ml}$ PBS were incubated with $100 \mu \mathrm{g}{ }^{125} \mathrm{I}$-labeled lactoferrin (specific activity, $6 \times 10^{5} \mathrm{cpm} / \mu \mathrm{g}$ protein) at $4^{\circ} \mathrm{C}$ and $37^{\circ} \mathrm{C}$ for $\mathbf{4 0} \mathrm{min}$. After incubation at the specified temperatures, trichomonads were washed twice with PBS and resuspended in $0.5 \mathrm{ml}$ PBS and transferred to another tube for the indicated times. Radioactivity was measured after pelleting of organisms as described in Materials and Methods. Each point represents the mean of three samples from a representative experiment. The standard deviation for each point never exceeded $10 \%$ of the mean.

in the electrophoretic mobility of either released or trichomonad-associated ${ }^{125} \mathrm{I}$ labeled lactoferrin was observed (data not shown), indicating the absence of parasite degradation of lactoferrin.

Concentration-dependent Acquisition of ${ }^{125}$ I-labeled Lactoferrin. Saturation binding of lactoferrin was achieved after incubation of $T$. vaginalis with increasing concentrations of iodinated ligand for $40 \mathrm{~min}$ at $4^{\circ} \mathrm{C}$, (Fig. 2). The binding kinetics of the labeled lactoferrin used in these assays was not affected by the iron content of this protein. Low-level association of transferrin with $T$. vaginalis was observed under similar experimental conditions. The overall extent of transferrin binding to the parasites never exceeded $10 \%$ of that observed for lactoferrin. Scatchard analysis (33) of the data for lactoferrin binding are shown 


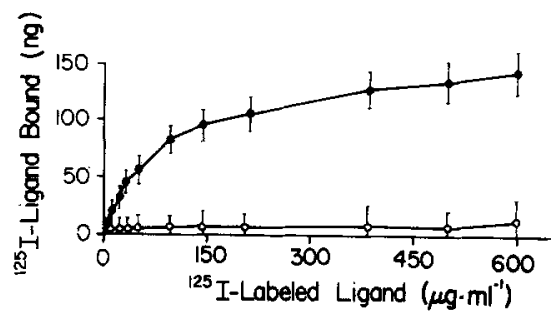

FIGURE 2. Concentration-dependent binding of ${ }^{125}$ I-labeled human lactoferrin (O) and transferrin $(O)$ to $T$. vaginalis. Cells were suspended at a density of $1 \times 10^{7}$ organisms in $0.5 \mathrm{ml}$ PBS and incubated with varying concentrations of ligand for $40 \mathrm{~min}$ at $4^{\circ} \mathrm{C}$. Parasite bound cpm was determined as described. Each data point represents the mean value of duplicate samples in three separate experiments.

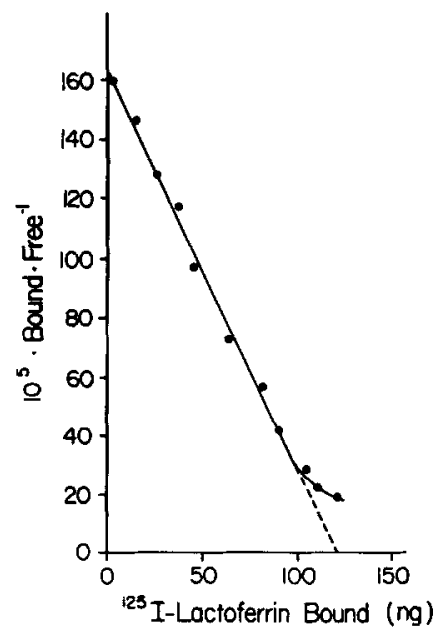

Figure 3. Scatchard plot analysis of data as presented in Fig. 2 which demonstrated saturation kinetics of ${ }^{125}$ I-labeled human lactoferrin binding to $T$. vaginalis.

in Fig. 3 and provided evidence for a single class of lactoferrin receptors with an apparent $K_{\mathrm{d}}$ of $1.0 \mu \mathrm{M}$. Low affinity (nonspecific) interactions were also evident at very high lactoferrin concentrations. The average number of trichomonad lactoferrin receptors was estimated to be $9 \times 10^{4}$ per cell.

Lactoferrin Receptor Specificity. Stoichiometric competition for the lactoferrin receptor was observed when unlabeled ligand was added to trichomonads incubated with ${ }^{125}$ I-labeled lactoferrin (Fig. 4). Unlabeled transferrin did not compete for ${ }^{125}$ I-lactoferrin binding, demonstrating the specificity of the trichomonad receptor for lactoferrin.

Affinity-purified Trichomonad-lactoferrin Receptors. The identification of the membrane components involved in lactoferrin binding was attempted using affinity chromatography. Electrophoretic analysis of material eluted from lactoferrin covalently coupled to cyanogen bromide-activated Sepharose is presented in Fig. 5. Lane $1 \mathrm{~A}$ shows ${ }^{35} \mathrm{~S}$-labeled proteins, with molecular weights (mol wts) of $178 \mathrm{Kd}$ and $75 \mathrm{Kd}$, eluted from the lactoferrin column with $3 \mathrm{M}$ potassium ferricyanide. Proteins with similar mol wts were identified when an extract of iodinated cells was used (lane $1 B$ ), confirming the surface origin of these 


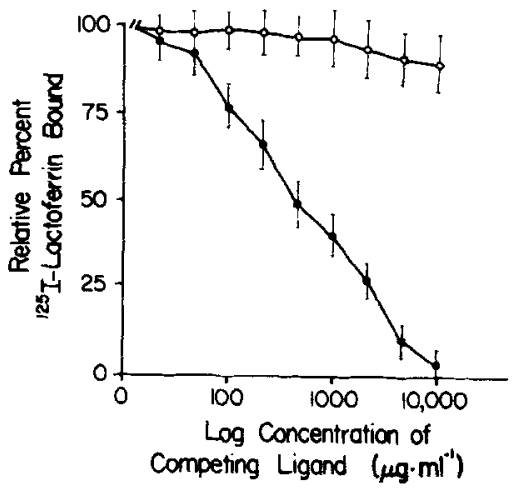

FIGURE 4. Specificity of acquisition of lactoferrin by $T$. vaginalis. A $1-\mathrm{ml}$ suspension of $1 \times$ $10^{7}$ trichomonads were simultaneously incubated for $40 \mathrm{~min}$ at $4^{\circ} \mathrm{C}$ with $300 \mu \mathrm{g}$ radioiodinated lactoferrin and varied amounts of unlabeled lactoferrin $(0)$ or transferrin (O). $100 \mu \mathrm{g}$ of unlabeled lactoferrin represents a ratio of 1:3 unlabeled to labeled protein. The amount of ${ }^{125}$ I-labeled lactoferrin bound to trichomonads in the absence or presence of competing ligand was determined as described in Materials and Methods. Each data point represents the mean value of duplicate samples from two separate experiments.

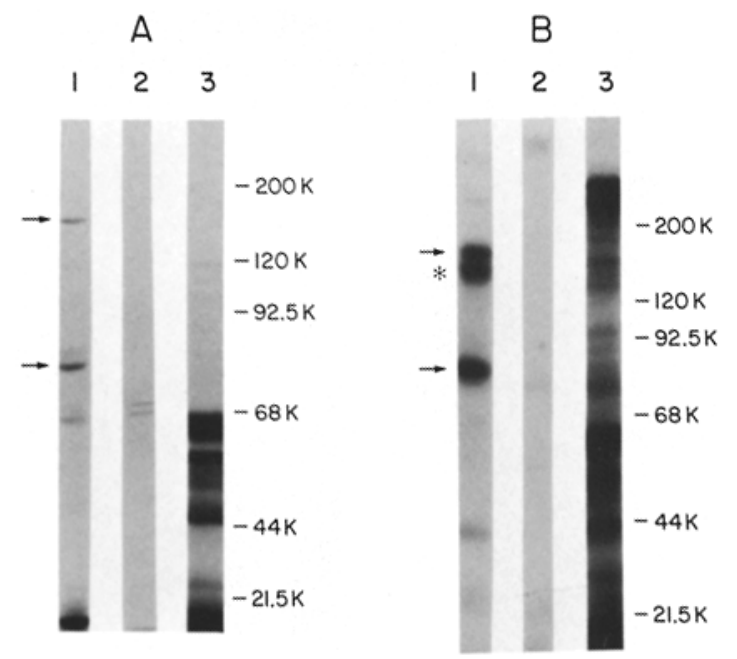

FIGURE 5. SDS-PAGE-radioautography of ${ }^{35}$ S-intrinsically $(A)$ and ${ }^{125}$ lextrinsically $(B)$ radiolabeled $T$. vaginalis proteins purified by lactoferrin-Sepharose affinity chromatography. The trichomonad proteins selectively bound to the lactoferrin column are shown in lane 1 . The absence of parasite proteins binding to transferrin-Sepharose as a control is shown in lane 2 . Lane 3 shows the protein gel patterns of radiolabeled $T$. vaginalis Zwittergent extracts. Molecular weight markers: myosin, $200 \mathrm{~K}$; beta-galactosidase, $120 \mathrm{~K}$; phosphorylase $\beta, 92.5$ $\mathrm{K}$; bovine serum albumin, $68 \mathrm{~K}$; ovalbumin, $44 \mathrm{~K}$; and soybean trypsin inhibitor $21.5 \mathrm{~K}(\mathrm{~K}=$ $10^{3}$ daltons). Arrows denote lactoferrin-binding proteins.

lactoferrin-binding proteins. The absence of reducing agent in the electrophoresis dissolving buffer yielded identical gel patterns. Lanes $2 A$ and $2 B$ illustrate the inability of ${ }^{35} \mathrm{~S}$-labeled or iodinated parasite proteins, respectively, to interact with transferrin-Sepharose under identical conditions. Lanes $3 A$ and $3 B$ represent patterns of radiolabeled proteins in the detergent extracts subjected to chromatography and show the enrichment on lactoferrin-Sepharose for specific 
parasite proteins. While the appearance of another (third) protein with a slightly lower mol wt by affinity chromatography of iodinated $T$. vaginalis extracts (Fig. 5 , asterisk) cannot be explained at present, the absence of the doublet band using the alternative method (Fig. 6) suggests it may represent nonspecific material.

Immunoprecipitation of Lactoferrin-receptor Complexes. Another approach for identification of trichomonad components that bind human lactoferrin involved a radioimmunoprecipitation-type assay (34) using monospecific antisera to lactoferrin. A detergent extract of intrinsically labeled $T$. vaginalis was incubated with lactoferrin and anti-lactoferrin antibodies. Immunoprecipitated trichomonad proteins that bind lactoferrin are shown in Fig. 6 (lane 1). These proteins possessed mol wts similar to those purified by affinity chromatography (Fig. 5). Increasing the concentration of lactoferrin in the reaction mixture resulted in increased immunoprecipitated radioactivity (data not shown). Addition of albumin or transferrin to the reaction mixture containing anti-lactoferrin serum did not result in precipitation of radiolabeled proteins (data not shown). Normal rabbit serum did not precipitate proteins under identical conditions (data not shown). The inability of transferrin and anti-transferrin antibodies to immunoprecipitate trichomonad proteins is shown in lane 2 . Finally, use of a detergent extract of iodinated $T$. vaginalis yielded equivalent results, reinforcing the surface orientation of the parasite lactoferrin receptors (data not shown).

$T$. vaginalis Uptake of Iron from Lactoferrin. We next examined the ability of these parasites to remove ${ }^{59} \mathrm{Fe}^{3+}$ from human ${ }^{59} \mathrm{Fe}$-lactoferrin. As can be seen in

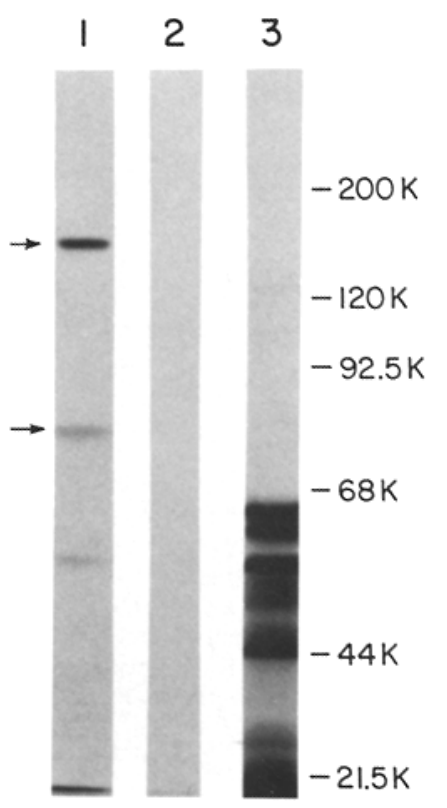

FIGURE 6. SDS-PAGE-radioautography following radioimmunoprecipitation of ${ }^{35} \mathrm{~S}$-labeled $T$. vaginalis lactoferrin-binding proteins. Specific proteins complexed with lactoferrin are shown in lane 1 . Lane 2 represents absence of $T$. vaginalis transferrin-binding proteins in a transferrin-antitransferrin mixture. Lane 3 shows the gel pattern of the Zwittergent extract of ${ }^{35} \mathrm{~S}$-labeled $T$. vaginalis used in this assay. Molecular weight markers are as indicated in the legend of Fig. 6 . Arrows denote lactoferrin-binding proteins. 
Fig. 7, T. vaginalis rapidly and efficiently removed ${ }^{59} \mathrm{Fe}$ from lactoferrin. On a molar basis, $T$. vaginalis acquired approximately 120 -fold more iron $(60 \mathrm{pM})$ at $37^{\circ} \mathrm{C}$ as compared with the steady-state concentration $(0.5 \mathrm{pM})$ of iron bound to the parasite surface at $4^{\circ} \mathrm{C}$. These data demonstrate parasite accumulation of iron in excess to the amounts of lactoferrin acquired by $T$. vaginalis at each time point at $37^{\circ} \mathrm{C}$. Consistent with our earlier observation (Fig. 2), T. vaginalis was unable to accumulate radioactive iron from transferrin (data not shown).

Attempts by us to show the intracellular disposition of iron through subcellular fractionation of $T$. vaginalis were unsuccessful. Therefore, pyruvate/ferredoxin oxidoreductase, an enzyme involved in trichomonal energy metabolism (23) whose activity may be dependent upon intracellular iron levels, was monitored as a marker for iron uptake. As can be seen in Table II, addition of ferrous sulfate (a source of free iron) to TYM-medium increased this enzyme's activity more than sixfold. A similar enhancement of activity was observed with lactoferrin-supplemented growth medium. Transferrin, apolactoferrin and apotransferrin, however, did not stimulate pyruvate/ferredoxin oxidoreductase activity above control values. Finally, enzyme activity remained high upon addition to medium of apotransferrin in the presence of iron-lactoferrin. These data indicate that iron uptake results from specific acquisition of human lactoferrin by $T$. vaginalis.

Comparative Lactoferrin Binding among $T$. vaginalis Isolates. Potential variability in lactoferrin binding among several $T$. vaginalis isolates was assessed in the cell binding assay. Excess levels of ${ }^{125}$ I-lactoferrin $(500 \mu \mathrm{g} / \mathrm{ml})$ were incubated with $1 \times 10^{7}$ parasites for $40 \mathrm{~min}$ at $4^{\circ} \mathrm{C}$. Lactoferrin binding (Table III) varied no more than $30 \%$, indicating little or no differences in receptor number among various trichomonal isolates.

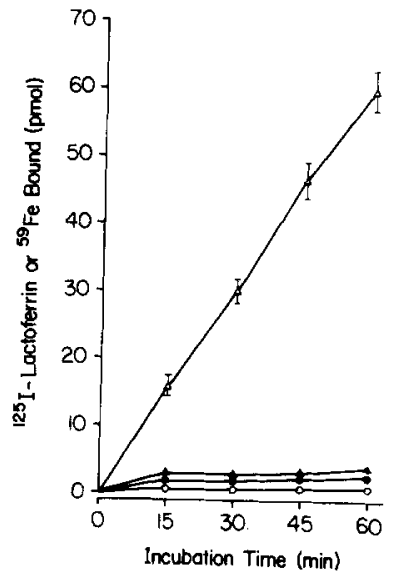

Figure 7. Time course iron $\left({ }^{59} \mathrm{Fe}\right)$ accumulation by $T$. vaginalis. Trichomonads $\left(1 \times 10^{7}\right)$ were resuspended in $0.5 \mathrm{ml} \mathrm{PBS}$ and incubated with $200 \mu \mathrm{g}$ of ${ }^{59} \mathrm{Fe}$-labeled lactoferrin $(\Delta, O)$ or ${ }^{125}$ I-labeled lactoferrin $(\Delta, \theta)$ at $37^{\circ} \mathrm{C}(\Delta, \Delta)$ and $4^{\circ} \mathrm{C}(\mathbf{O}, 0)$ for the indicated time points. The amount of radiolabel associated with $T$. vaginalis was determined as before. Each data point represents the mean value of duplicate samples from three experiments. 
TABLE II

Pyruvate/Ferredoxin Oxidoreductase Activity

\begin{tabular}{|c|c|}
\hline Medium* supplement & $\begin{array}{l}\text { Activity (nmol min } \\
\text { of protein) }\end{array}$ \\
\hline Control-no addition & $260 \pm 50^{5}$ \\
\hline Ferrous sulfate ${ }^{8}$ & $1,670 \pm 290$ \\
\hline Lactoferrin' & $1,830 \pm 330$ \\
\hline Apolactoferrin ${ }^{\ddagger}$ & $260 \pm 60$ \\
\hline Transferrin & $230 \pm 80$ \\
\hline Apotransferrin ${ }^{\ddagger}$ & $270 \pm 90$ \\
\hline Lactoferrin + apotransferrin & $1,780 \pm 350$ \\
\hline
\end{tabular}

* $1 \times 10^{7} T$. vaginalis organisms were grown in TYM medium supplemented with human low density lipoproteins at a concentration equivalent to that found in $10 \%$ plasma (17).

$\ddagger$ As described in Materials and Methods.

$25 \mathrm{mM}$ ferrous ammonium sulfate was prepared in $50 \mathrm{mM}$ sulfosalicylic acid. Final iron concentration in medium was $1.0 \mu \mathrm{g} / \mathrm{ml}$.

$100 \mu \mathrm{g} / \mathrm{ml}$ final concentration of $30 \%$ iron saturated lactoferrin or transferrin was used in the incubation medium as described above.

"Mean values of duplicate samples from three independent assays.

TABLE III

Representative Lactoferrin Binding among $T$. vaginalis Strains

\begin{tabular}{cc}
\hline Strain designation* & Lactoferrin avidly bound (ng) \\
\hline NYU 286 & $120^{\ddagger}$ \\
NYU 272 & 110 \\
NYU IR 78 & 100 \\
ATCC 30001 & 130 \\
ATCC 30236 & 140 \\
RU 375 & 140 \\
JHHR & 120 \\
JHHW & 140 \\
\hline
\end{tabular}

* See Materials and Methods.

$¥ 1 \times 10^{7} T$. vaginalis organisms were grown in TYM-medium supplemented with human low density lipoproteins to a density of $\sim 1 \times 10^{6}$ organisms $/ \mathrm{ml}$. Parasites were washed and then resuspended in $500 \mu \mathrm{g} /$ $\mathrm{ml}$ of ${ }^{125} \mathrm{I}$-lactoferrin $\left(400 \mathrm{cpm} / \mathrm{ng}\right.$ protein) for $40 \mathrm{~min}$ at $4^{\circ} \mathrm{C}$. Cells were then washed and radioactivity bound determined as described in Materials and Methods.

Mean value of triplicate samples. Deviations never exceeded $20 \%$ of reported values.

\section{Discussion}

Successful parasitism by some pathogenic microorganisms is related to the uptake of host substances such as iron. Host iron is usually bound by specific molecules such as transferrin and lactoferrin, glycoproteins with high binding affinities for iron found in serum or vaginal mucosa, respectively. The acquisition of these host proteins by $T$. vaginalis through receptor-mediated processes might represent mechanisms by which these pathogenic human trichomonads acquire iron, and enhance their survival within the host environment.

In this report the data indicate that $T$. vaginalis possesses specific receptors for human lactoferrin. Each cell possesses $\sim 9 \times 10^{4}$ receptors with an apparent $K_{\mathrm{d}}$ 
estimated to be $1.0 \mu \mathrm{M}$ (Fig. 3). The rate of association of the ligand with these parasites is equally rapid whether binding takes place at $4^{\circ} \mathrm{C}$ or $37^{\circ} \mathrm{C}$ (Fig. 1), supporting the idea of receptor-mediated acquisition of this host substance. Transferrin, an iron transport protein found in plasma, does not bind to $T$. vaginalis with high affinity (Fig. 2) and fails to compete for the binding of ${ }^{125} \mathrm{I}$ labeled lactoferrin to intact trichomonads (Fig. 4). The ability of $T$. vaginalis to bind lactoferrin more effectively than plasma-derived transferrin may be a significant factor in the non-invasive nature of this parasite.

Chromatography of a Zwittergent extract of intrinsically or extrinsically labeled $T$. vaginalis on a lactoferrin-Sepharose affinity matrix resulted in purification of two trichomonad proteins (Fig. 5). Similar results were obtained using a different experimental approach involving a radioimmunoprecipitation-type assay system (34). An extract of ${ }^{35} \mathrm{~S}$-labeled parasite proteins in both experiments implicated two polypeptides $(178 \mathrm{Kd}$ and $75 \mathrm{Kd})$ as the putative lactoferrin receptors (Figs. 5 and 6 ).

The binding of lactoferrin to $T$. vaginalis results in intracellular iron accumulation (Fig. 7). These data did not allow us to discriminate whether iron is removed from lactoferrin at the parasite surface or whether lactoferrin is internalized before iron uptake. The release of lactoferrin after binding to the trichomonad receptor may indicate that the former sequence of events takes place allowing for a continuous turnover of exogenous lactoferrin.

An increase in the activity of pyruvate/ferredoxin oxidoreductase, an intracellular enzyme important for electron transport in this facultative anaerobic protozoan, resulted from $T$. vaginalis acquisition of human lactoferrin. These results are consistent with the importance of iron-containing proteins to the metabolic processes of $T$. vaginalis cells (23). These data and a report demonstrating the increased virulence of trichomonads following iron injection in mice (25) suggest that the trichomonad receptors for human lactoferrin contribute to the virulence of this parasite.

These data and previous work (15-17) have made evident the usefulness of host protein acquisition by $T$. vaginalis through processes that represent a clear departure from nonspecific coating of the parasite. It is possible that receptors binding biologically important host macromolecules such as lactoferrin, lipoproteins, $\alpha_{1}$-antitrypsin, and other host molecules (15-17) contribute to the parasitic capabilities of this protozoan. We hope this information and our approaches will allow us to better understand the biology of this host-parasite relationship.

\section{Summary}

Lactoferrin acquisition and iron uptake by pathogenic Trichomonas vaginalis was examined. Saturation binding kinetics were obtained for trichomonads using increasing amounts of radioiodinated lactoferrin, while no significant binding by transferrin under similar conditions was achieved. Only unlabeled lactoferrin successfully and stoichiometrically competed with ${ }^{125}$ I-labeled lactoferrin binding. Time course studies showed maximal lactoferrin binding by $30 \mathrm{~min}$ at $37^{\circ} \mathrm{C}$. Data suggest no internalization of bound lactoferrin. The accumulation of radioactivity in supernatants after incubation of $T$. vaginalis with ${ }^{125}$ I-labeled lactoferrin and washing in PBS suggested the presence of low affinity sites for 
this host macromolecule. Scatchard analysis indicated the presence of 90,000 receptors per trichomonad with an apparent $K_{\mathrm{d}}$ of $1.0 \mu \mathrm{M}$. Two trichomonad lactoferrin binding proteins were identified by affinity chromatography and immunoprecipitation of receptor-ligand complexes. A 30-fold accumulation of iron was achieved using ${ }^{59} \mathrm{Fe}$-lactoferrin when compared to the steady state concentration of bound lactoferrin. The activity of pyruvate/ferrodoxin oxidoreductase, an enzyme involved in trichomonal energy metabolism, increased more than sixfold following exposure of the parasites to lactoferrin, demonstrating a biologic response to the receptor-mediated binding of lactoferrin. These data suggest that $T$. vaginalis possesses specific receptors for biologically relevant host proteins and that these receptors contribute to the metabolic processes of the parasites.

We thank Miklos Müller and Tom Gorrell of The Rockefeller University for their gracious advice and assistance rendered during the oxidoreductase enzyme experiments. We gratefully acknowledge Barry Muhoberac and Charlie Gauntt for allowing us to use their equipment and Sam Witherspoon for his advice and help in certain experiments. The advice and critical review of this manuscript by Joel Baseman is appreciated. The secretarial help of Jill Sapp and the efforts by Mrs. Kathy Mergele of the LaLeche League for obtaining for us the human breast milk are especially appreciated.

Received for publication 27 April 1984.

\section{References}

1. Ackers, J. P. 1982. Immunology of amebas, glardia, and trichomonads. In Immunology of Human Infection, Vol. 9, Part II, Viruses and Parasites; Immunodiagnosis and Prevention of Infectious Diseases. A. J. Nahmias and R. J. O'Reilly, editors. Plenum Publishing Corp., New York. 403-443.

2. Honigberg, B. M. 1978. Trichomonads of importance in human medicine. In Parasitic Protozoa II. J. P. Kreier, editor. Academic Press, New York. 275-392.

3. Spence, M. R., D. H. Hollander, J. Smith, L. McCaig, D. Sewell, and M. Brockman. 1980. The clinical and laboratory diagnosis of Trichomonas vaginalis infection. Sex. Transm. Dis. 7:168.

4. Kreiger, J. N. 1981 . Urologic aspects of trichomoniasis. Invest. Urol. I 8:4I 1.

5. Alderete, J. F., and E. Pearlman, 1983. Pathogenic Trichomonas vaginalis cytotoxicity to cell culture monolayers. Br. J. Vener. Dis. 60:99.

6. Kreiger, J. N., M. A. Poisson, and M. F. Rein. 1983. Beta-hemolytic activity of Trichomonas vaginalis correlates with virulence. Infect. Immun. 41:1291.

7. Capron, A., J. P. Dessaint, D. Camus, and M. Capron. 1976. Some immune mechanisms in host-parasite relationships. In Biochemistry of Parasites and Host-Parasite Relationships. H. Van den Bossche, editor. Elsevier-North Holland Biomedical Press, Amsterdam. 263-282.

8. Bloom, B. R. 1979. Games parasites play: how parasites evade immune surveillance. Nature (Lond.). 279:21.

9. Whitnack, E., and E. H. Beachey. 1982. Antiopsonic activity of fibrinogen bound to $M$ protein on the surface of group A streptococci. J. Clin. Invest. 69:1042.

10. Simonson, C., D. Brenner, and 1. W. DeVoe. 1982. Expression of a high-affinity mechanism for acquisition of transferrin iron by Neisseria meningitidis. Infect. Immun. 36:107. 
11. Bullen, J. J., H. J. Rogers, and E. Grifiths. 1978. Role of iron in bacterial infection. Curr. Top. Microbiol. Immunol. 80:1.

12. Peterson, K. M., J. B. Baseman, and J. F. Alderete. 1983. Treponema pallidum receptor binding proteins interact with fibronectin. J. Exp. Med. 157:1958.

13. Ouaissi, M. A., D. Afchain, A. Capron, and J. A. Grimaud. 1984. Fibronectin receptors on Trypanosoma cruci trypomastigotes and their biological function. Nature (Lond.). 308:380.

14. Brenner, D., I. W. DeVoe, and B. E. Holbein. 1981. Increased virulence of Neisseria meningitidis following in vitro iron-limited growth at low $\mathrm{pH}$. Infect. Immun. 33:59.

15. Peterson, K. M., and J. F. Alderete. 1982. Host plasma proteins on the surface of pathogenic Trichomonas vaginalis. Infect. Immun. 37:755.

16. Peterson, K. M., and J. F. Alderete. 1983. Acquisition of $\alpha 1$-antitrypsin by a pathogenic stain of Trichomonas vaginalis. Infect. Immun. 40:640.

17. Peterson, K. M., and J. F. Alderete. 1984. Selective acquisition of plasma proteins by Trichomonas vaginalis and human lipoproteins as a growth requirement for this species. Mol. Biochem. Parasitol. In press.

18. Aisen, P. 1980. The transferrins. In Iron in Biochemistry and Medicine, Vol. 2. A. Jacobs and M. Worwood, editors. Academic Press, Inc., New York. 87-129.

19. Aisen, P., and A. Leibman. 1972. Lactoferrin and transferrin: a comparative study. Biochem. Biophys. Acta. 257:314.

20. Masson, P. L., J. F. Heremans, and C. H. Dive. 1966. An iron-binding protein common to many external excretions. Clin. Chim. Acta. 14:735.

21. Masson, P. L., J. F. Heremans, J. J. Prignot, and G. Wauters. 1966. Immunohistochemical localization and bacteriostatic properties of an iron-binding protein from bronchial mucus. Thorax. 21:538.

22. Masson, P. L., J. F. Heremans, and E. Schonne. 1969. Lactoferrin, an iron binding protein in neutrophilic leukocytes. J. Exp. Med. 130:643.

23. Marczak, R., T. E. Gorrell, and M. Müller. 1983. Hydrogenosomal ferredoxin of the anaerobic protozoan, Tritrichomonas foetus. J. Biol. Chem. 258:12427.

24. Müller, M., and T. E. Gorrell. 1983. Metabolism and metronidazole uptake in Trichomonas vaginalis isolates with different susceptibilities. Antimicrob. Agents Chemother. 24:667.

25. Budilova, M., and J. Kulda. 1977. Further studies on the effect of ferric ammonium citrate on the virulence of Tritrichomonas foetus to mice. J. Protozool. 24:49.

26. Diamond, L. S. 1968. Techniques of axenic culture of Entomoeba histolytica schaudinni, 1403 and E. histolytica-like amaebae. J. Parasitol. 54:1047.

27. Boeseman-Finkelstein, M., and R. A. Finkelstein. 1982. Sequential purification of lactoferrin, lysozyme and secretory immunoglobulin A from human milk. FEBS (Fed. Eur. Biochem. Soc.) Lett. 144:1.

28. Mickelsen, P. A., E. Blackman, and P. F. Sparling. 1982. Ability of Neisseria gonorrhoeae, Neisseria meningitidis, and commensal Neisseria species to obtain iron from lactoferrin. Infect. Immun. 35:915.

29. Garvey, J. S., N. E. Cremer, and D. H. Sussdorf. 1977. ${ }^{125}$ I or ${ }^{131}$ I-labeled proteins. In Methods in Immunology. D. H. Campbell, editor. W. A. Benjamin, Inc., Reading, MA. 171-182.

30. Laemmli, U. K. 1970. Cleavage of structural proteins during the assembly of the head of bacteriophage $T_{4}$. Nature (Lond.). 227:680.

31. Alderete, J. F. 1983. Identification of immunogenic and antibody-binding membrane proteins of pathogenic Trichomonas vaginalis. Infect. Immun. 40:284.

32. Cuatrecasas, P., M. Wilchek, and C. B. Antisen. 1968. Selective enzyme purification by affinity chromatography. Proc. Natl. Acad. Sci. USA. 61:636. 
33. Feldman, H. A. 1972. Mathematical theory of complex ligand-binding systems at equilibrium: some methods for parameter fitting. Anal. Biochem. 48:317.

34. Proia, R. L., D. A. Hart, R. K. Holmes, K. V. Holmes, and L. Eidels. 1979. Immunoprecipitation and partial characterization of diphtheria toxin-binding glycoproteins from surface of guinea pig cells. Proc. Natl. Acad. Sci. USA. 76:685. 